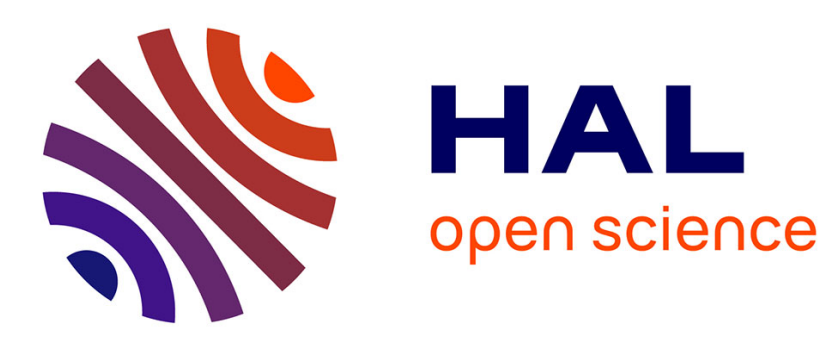

\title{
Syllabic inventory of a Western Naxi dialect, and correspondence with Joseph F. Rock's transcriptions
}

Boyd Michailovsky, Alexis Michaud

\section{To cite this version:}

Boyd Michailovsky, Alexis Michaud. Syllabic inventory of a Western Naxi dialect, and correspondence with Joseph F. Rock's transcriptions. Cahiers de linguistique - Asie Orientale, 2006, 35(1), pp. 3-21. hal-00134940

\section{HAL Id: hal-00134940 \\ https://hal.science/hal-00134940}

Submitted on 5 Mar 2007

HAL is a multi-disciplinary open access archive for the deposit and dissemination of scientific research documents, whether they are published or not. The documents may come from teaching and research institutions in France or abroad, or from public or private research centers.
L'archive ouverte pluridisciplinaire HAL, est destinée au dépôt et à la diffusion de documents scientifiques de niveau recherche, publiés ou non, émanant des établissements d'enseignement et de recherche français ou étrangers, des laboratoires publics ou privés. 
Reference Type: Journal Article

Author: Michailovsky, Boyd; Michaud, Alexis

Year: 2006

Title: Syllabic inventory of a Western Naxi dialect, and correspondence with Joseph F. Rock's transcriptions

Journal: Cahiers de linguistique - Asie Orientale

Volume: 35

Issue: 1

Pages: $3-21$

PREPRINT VERSION 


\title{
Syllabic inventory of a Western Naxi dialect, and correspondence with Joseph F. Rock's transcriptions
}

\begin{abstract}
Naxi is a Sino-Tibetan language close to the Burmese-Yi subgroup; its precise genetic affiliation is still a matter of debate. After a short review of some earlier publications on Naxi, this paper offers new data (the syllabic inventory of a Western Naxi dialect, based on first-hand fieldwork), and a guide to an older resource: the correspondences between our transcriptions and the script invented by the 'botanist-explorer' Joseph F. Rock are set out, offering a practical tool for deciphering the somewhat perplexing, idiosyncratic romanised transcription used in his Na-Khi-English Encyclopedic Dictionary, a book of historical importance in Naxi studies.
\end{abstract}

Keywords : Naxi; syllable; phonemics; Joseph Rock; transcription.

\section{Inventaire syllabique d'un dialecte occidental de la langue naxi, et correspondance avec les transcriptions de J. Rock}

Résumé : Le naxi est une langue sino-tibétaine proche du sous-groupe birman-yi ; son affiliation génétique précise demeure incertaine. Après un bref passage en revue de travaux existants sur la langue naxi, le présent travail apporte des données nouvelles (l'inventaire syllabique d'un dialecte occidental du naxi, fondé sur des données recueillies de première main), ainsi qu'un guide pour l'utilisation d'une publication déjà ancienne: des correspondances sont établies avec la notation romanisée inventée par Joseph Rock, «explorateur-botaniste» dont le Dictionnaire encyclopédique na-khi-anglais présente une importance historique. Cet outil permet le déchiffrement de la transcription idiosyncratique de cet auteur.

Mots-clefs : naxi ; syllabe ; phonématique ; Joseph Rock ; transcription.

Boyd Michailovsky, Langues et Civilisations à Tradition Orale, UMR 7107 CNRS-Universités Paris 3 et Paris 4, boyd.michailovsky@vjf.cnrs.fr

Alexis Michaud, Laboratoire de Phonétique et Phonologie, UMR 7018 CNRS-Sorbonne Nouvelle, alexis.michaud@univ-paris3.fr 
Introductory note

Naxi is a Sino-Tibetan language; its precise genetic affiliation, and especially its position vis-à-vis the Burmese-Yi subgroup, is still a matter of debate. As a twofold contribution to Naxi studies, the present paper offers new data (the syllabic inventory of a Western Naxi dialect, based on first-hand fieldwork), and a guide to an older resource: the Na-Khi-English Encyclopedic Dictionary published by the 'botanist-explorer' Joseph F. Rock. Rock created a somewhat perplexing, and definitely idiosyncratic, romanised transcription for Naxi; a practical tool for deciphering this script is here proposed, by establishing the correspondences between our transcriptions and the script invented by Rock. These developments will be preceded by a short presentation of the Naxi language, the Naxi nationality, and Naxi studies.

1. Short presentation of the Naxi language and the Naxi nationality

The Naxi language is a Sino-Tibetan language mainly spoken in Yunnan, China (for more details, see, in the present issue, "Three extreme cases of neutralisation: nasality, retroflexion and liprounding in Naxi"). Its autonym in the Western dialects is /nò hi-/; its present-day Chinese name is $\mathrm{na}^{4} \mathrm{xi}^{1} \mathrm{yu}^{3}$ 纳西语. The Naxi nationality encompasses populations that do not perceive themselves unanimously as members of one and the same 'ethnic group'. This situation is by no means exceptional: any division of the complex reality of human societies into hard-and-fast categories is bound to be inadequate in some respects. After 1949, 'nationalities' $\left(\mathrm{min}^{2} \mathrm{zu}^{2}\right.$ 民族) were defined on the basis of a variety of factors which included long-standing Chinese anthroponymic traditions, as well as the political and socio-economic projects of the young People's Republic of China.

As part of the national linguistic survey conducted in the 1950s, Naxi was investigated in 1956 by eight linguists; some of the data 
collected were later published in book form (He Jiren and Jiang Zhuyi 1985). On the basis of these data, it was concluded that Naxi comprised Western dialects and Eastern dialects. At present, speakers of Eastern Naxi claim to be a different people from the Naxi, and ask for recognition as a distinct nationality, under the name 'Mosuo' ( $\mathrm{mo}^{2} \mathrm{suo}^{1}$ 摩梭). To make a long story short, 'Mosuo' (and 'Moxie' 麼些 $\mathrm{mo}^{1} \mathrm{xie}^{1}$ ) are names formerly used in the Chinese records, which were officially replaced after 1949 by 'Naxi' ( $\mathrm{na}^{4} \mathrm{xi}^{1}$ 纳西), the latter name being used for the entire group. (Thus, the dictionary of pictograms originally published by Li Lincan, Zhang Kun and $\mathrm{He}$ Cai as Dictionary of Moxie pictograms [Hong Kong, 1953] was reprinted in 2001 on the mainland under the title Dictionary of Naxi pictograms.) 'Mosuo', originally a derogatory term, is nonetheless favoured by the speakers of Eastern Naxi themselves. Indeed, from their vantage point, this name has several advantages. The words 'Mosuo' and 'Naxi' are clearly distinct from each other phonetically, which satisfies the desire of the 'Mosuo' to appear as different from the Naxi, whereas using an autonym would bring out similarities rather than differences: the autonyms of the communities that claim recognition as 'Mosuo' are [nò $\left.{ }^{-}\right]$, [nō $\left.\bar{z}\right]$ or [nā hĩ $\left.{ }^{-}\right]$, depending on the dialect (He Jiren et al. 1985:107), i.e. names that are so close to the autonyms used by the 'Naxi' ([nò hi $\left.{ }^{-}\right]$or [nò hĩ '], again depending on the dialect) that they might cast doubt on the legitimacy of a sharp separation. Moreover, the term 'Mosuo' presents the twofold advantage of being a term of some antiquity, having been used in the Chinese chronicles since the Tang dynasty (唐朝, 618-907), and of having fallen into disuse in the middle of the $20^{\text {th }}$ century, which lends it a quaint charm and a touch of mystery that constitute major assets for tourism - now an important part of the local economy.

From a historical point of view, the geographic extent of Western Naxi by and large coincides with the sphere of influence of the 
(Naxi) rulers of the city of Lijiang, the Mu feudal lords (木氏土司 $\mathrm{mu}^{4} \mathrm{shi}^{4} \mathrm{tu}^{3} \mathrm{si}^{1}$ ), who were vassals of the Chinese emperor in the Ming dynasty (明朝, 1368-1644) and the Qing dynasty (清朝, 1644-1911). Eastern Naxi is spoken in an area which was not under the control of the feudal lords of Lijiang, and was under Tibetan influence: see the history of the Naxi people by Guo Dalie and He Zhiwu (1999), as well as the observations of Charles McKhann $(1995,1998)$ about the divide between 'Mosuo' and 'Naxi', and of Erik Mueggler (2001) about the situation of the ethnic minorities of Yunnan in contemporary China (The Age of Wild Ghosts: Memory, Violence, and Place in Southwest China).

The Naxi/Mosuo have been the object of fairly extensive ethnological investigation (many ethnologues favouring the appellation $\mathrm{Na}$ ) since the description of Jacques Bacot (1913): see in particular Jackson (1979), Cai Hua (1997), Mathieu (2003). Less is known about the history of the languages and populations of the area.

2. A brief note on linguistic studies of Naxi. The historical importance of J.F. Rock's publications

Overviews of research into the Naxi language and culture are proposed by Harald Bøckman (1988: Naxi studies in China. A research report), Anthony Jackson (1989: "Naxi studies: past, present and future") and Bu Jinrong (1999). From a linguistic point of view, the Western dialects are better documented than the Eastern dialects: see, in particular, Li Lincan, Zhang Kun et al. 1953; Mazaudon and Michailovsky 1979; Fu Maoji 1984; He Jiren et al. 1985; Fang Guoyu and He Zhiwu 1995; Pinson 1998.

A dictionary of Naxi was published by Joseph F. Rock (19631972); by its scope, it is an important linguistic resource. A 'botanist-explorer' (to quote the title of the biography by S.B. Sutton: Sutton 1974), Rock did not have training in the International Phonetic Alphabet; the phonetic notations that he 
created are idiosyncratic, and require more explanation than their author himself provides in his dictionary (on pages xxxi-xxxv). Readers interested to learn more about the phonetic realisation of the words transcribed by Rock may be put off by shortcomings of his transcription, such as the use of several notations for one and the same syllable.

However, as mentioned by Bradley (1975), Rock's notations are by and large consistent. The correspondences with the International Phonetic Alphabet were first established in 1979 by Boyd Michailovsky, on the basis of a lexicon elicited from two informants (Mazaudon and Michailovsky 1979): these data were compared with the corresponding entries in Rock's dictionary. (A short, practical guide for using Rock's transcriptions was prepared at the time, but it remained unpublished.) The correspondences were recently checked, and somewhat improved, on the basis of new data on Naxi dialects collected by Alexis Michaud. For convenience, the correspondences are placed inside table 1, which shows the phonemic inventory of the Naxi dialect of AS (on which more detail is provided in section 3 below). It is hoped that this can serve as a practical tool for using Rock's data.

Rock indicates that "The dialect selected for the dictionary is the one spoken in the Li-chiang District but not in the town of Lichiang proper where the populace is unable to pronounce certain ${ }^{1} \mathrm{Na}-{ }^{2} \mathrm{khi}$ sound complexes [i.e. syllables] due to the fact that there is an infusion of Chinese among the inhabitants, just as there is a Tibetan infusion in the language used by ${ }^{1} \mathrm{Na}-{ }^{2}$ khi living in the West on the Tibetan border. It is the ${ }^{1} \mathrm{Na}-{ }^{2} \mathrm{khi}$ language spoken in the villages to the north and west of Li-chiang in the Yangtze Valley. The villages of La-pao 刺寶 and those northeast of the latter, within a distance of only sixty to eighty miles, speak a dialect not easily understood by the villagers of the actual plain of Lichiang. The dialect spoken at Lu-tien 魯甸, to the west of Lichiang, is very much mixed with Tibetan and contains sounds 
which do not occur in the purer Li-chiang District speech" (pp. xxvi-xvii). There appear to be very slight differences between the dialect recorded by Rock and the AS dialect; most correspondences are straightforward, but an uncertainty remains concerning the phonetic interpretation of the syllables written by Rock as $t$ 'khye, tgkye, ngye: the corresponding words have rhyme /a/ in the AS dialect, rhyme $/ x /$ in the town of Lijiang ('Dayanzhen dialect'), e.g. 'excrement' is ${ }^{2} t$ 'khye in Rock's dictionary, $/ \mathrm{k}^{\mathrm{h}} \mathrm{ja} / \mathrm{in} \mathrm{AS}, / \mathrm{k}^{\mathrm{hj}} \mathrm{j} / \mathrm{in}$ Lijiang. In the dialect investigated by Rock, the rhyme of these words is apparently different from both $/ \mathrm{ja} /$ and $/ \mathrm{j} 2 /$; we presume it to be / $\mathrm{e}$ /, a rhyme which is present in AS (in other combinations), though marginally. The equivalents of t'khye, tgkye, ngye would then be / $\mathrm{k}^{\mathrm{h}} \mathrm{ue} /$, /kue/ and /ngue/, respectively.

The correspondences presented here rely solely on volume I of the dictionary, not on volume II, which is devoted to proper names. It may thus be that volume II contains notations for which no equivalent is proposed here.

Judging from Rock's notations, the elements of the Naxi phonemic system that caused most difficulty for him were

(i) the back, unrounded vowel / $\mathrm{w} /$ and its allophones $[\mathrm{z}]$ and [ z. ], the former after an apico-alveolar fricative or affricate, the latter after a retroflex fricative or affricate. In Chao Yuen-ren's transcription system, in common use in China though not included in the 1996 version of the International Phonetic Alphabet, the former is written / 1 / and the latter / $\mathrm{l}$;

(ii) the rhotic vowel / $/ x /$;

(iii) $/ \mathrm{Y} /$, which acts as syllable nucleus, belonging in the paradigm of rhymes (it cannot appear as an initial).

These phonemes are common in the area but definitely foreignsounding to Rock's German ear (he was born in Austria). 
One syllable does not appear in table 1, in order to save a column throughout the table: the syllable $/ \mathrm{k}^{\mathrm{h}} \mathrm{jo} /$, which (in Rock's dictionary as well as in our data) is only attested in one single word: as the first syllable of the word 'ant', $/ \mathrm{k}^{\mathrm{h} j} \mathrm{l} \mathrm{lo} /$; this syllable is written by Rock as t'khyo.

\section{Syllabic inventory of the /ā sə̀/ dialect (for short: 'AS dialect')}

The syllabic inventory presented below is that of the Western dialect of Naxi spoken in the village of /ā sə̀/, hamlet of /lé p p lò/ (in Chinese: li $^{4}$ jiang ${ }^{1} \mathrm{gu}^{3}$ cheng ${ }^{2} \mathrm{qu}^{1}$, wen ${ }^{2}$ hua $^{4}$ xing $^{2}$ zheng $^{4}$ cun $^{1}$, leng ${ }^{3} \mathrm{bu}^{4} \mathrm{luo}^{2} \mathrm{zi}^{4} \mathrm{ran}^{2} \mathrm{cun}^{1}$ 丽江古城区, 文化行政村, 冷不罗自然村), abbreviated here as AS. This dialect possesses a larger phonemic inventory than the dialect of the city of Lijiang (Dayanzhen).

Naxi is a monosyllabic language without final consonants or consonant clusters. Most syllables are simply made up of a consonant and a vowel; syllabic structure is $(\mathrm{C})(\mathrm{G}) \mathrm{V}$, where $\mathrm{C}$ is a consonant, $\mathrm{G}$ a semi-vowel $/ \mathrm{w} /$ or $/ \mathrm{j} /$ (with a severely restricted distribution), and $\mathrm{V}$ a vowel; brackets indicate optional constituents.

Table 1 presents the initial+rhyme combinations attested in the AS dialect, and their phonetic realisation. Marginal combinations are placed inside brackets. A paper published in the present volume ("Three extreme cases of neutralisation: nasality, retroflexion and lip-rounding in Naxi") addresses the issue of the opposition between apico-alveolar and retroflex phonemes and its neutralisation in most contexts, as well as the possibility of an alternative analysis recognising medial semi-vowels $/ \mathrm{w} /$ and $/ \mathrm{j} /$. Tones are not indicated, as any of the combinations in table 1 can appear with any of the three basic lexical tones of Naxi (High, Mid and Low). 


\begin{tabular}{|c|c|c|c|c|c|c|}
\hline & & & & & & $\ddot{\Xi}$ \\
\hline 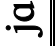 & $\stackrel{\Xi}{.}$ & & & & & \\
\hline \&. &.$\not$ & $\cong$ & 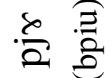 & & : & 兽 寻 \\
\hline$\frac{1}{3}$ & $\widehat{0}$ & & & & & \\
\hline 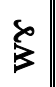 & है & & & & & \\
\hline $\mathbb{3}$ & 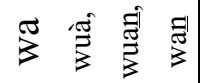 & & & & & \\
\hline$\vec{b}$ & 采 & & & & & \\
\hline$>$. & $>\overline{5}$ & $\stackrel{m}{a}$ & 离. '言 & 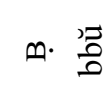 & 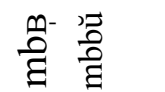 & छे \\
\hline co & is & $=\frac{20}{0}$ & 胥 & 8 & 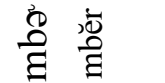 & 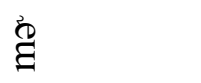 \\
\hline 0 & (્ర & $\Rightarrow \ddot{0}$ & $\ddot{2}$ : & 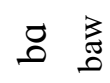 & 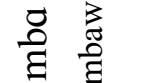 & $\stackrel{g}{g}$ \\
\hline$\infty$ & $\sigma$. & $=\ddot{0}$ & ڤ્ق & อี & 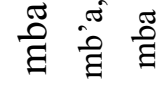 & $\stackrel{\Xi \Xi}{\Xi}$ \\
\hline 0 & 210 & $\cong$ & $\stackrel{2}{2}$ & & & $\stackrel{̊}{\sharp}$ \\
\hline so & $\oiiint$ & 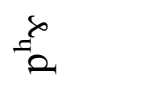 & $\hat{b}$ & كُ & $\begin{array}{l}\widehat{\delta} \\
\text { ह्छ }\end{array}$ & 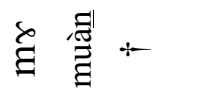 \\
\hline 0 & e & $=\frac{0}{2}$ & 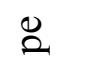 & ه: & 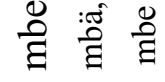 & $\dddot{g}: \because$ \\
\hline$=$ & $\xi \xi$ & $\Rightarrow=$ & $\bar{z}, \frac{1}{0}$ & $\tilde{\Xi}$ & है है & 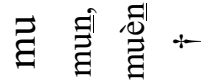 \\
\hline$B$ & 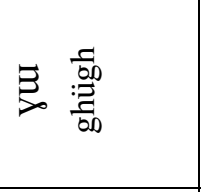 & 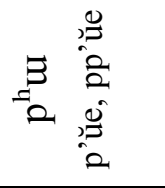 & 总 & 罗 & $\begin{array}{l}\text { है } \\
\text { है }\end{array}$ & 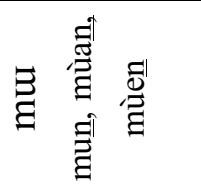 \\
\hline$\lambda$ & $\geqq:$ & 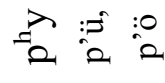 & 를 : & bे: & है $>$ : & 肴苛 \\
\hline.- & $:=\lesssim$ & $\ddot{\ddot{z}}: \vec{a}$ & $\overline{2} \overline{0}$ & $\overrightarrow{0}$ & :ี & $\bar{\Xi} \bar{\Xi}$ \\
\hline & $Q$ & $=$ & $=$ & م & है & $\Xi$ \\
\hline
\end{tabular}




\begin{tabular}{|c|c|c|c|c|c|c|c|c|c|c|c|}
\hline . & & & & & & & & & & & \\
\hline$\stackrel{ \pm}{\sim}$ & & & & & & & & & & & \\
\hline$\therefore$ & & $\Xi$ & & & & & & & & & \\
\hline$\underline{\varepsilon}$ & & & & $\stackrel{\delta}{\sigma}$ & & & & & & $\varrho$ & \\
\hline ही & & & & & & & 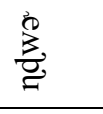 & & & & \\
\hline$\xi$ & & & & & & & & & & & \\
\hline$\tilde{3}$ & & & & & & & & & & & \\
\hline$\xi$ & & & & & & & & & & & \\
\hline$>$. & $\pm z$ & $z \cdot \frac{z}{0}$ & & $\frac{z}{2}$ & & $\frac{8}{g}$ & & $\geq \geq$ & & ঔ & \\
\hline i & $=$ & & 必尊 & & to & & 曾 & & 它道 & & $\stackrel{\phi}{\stackrel{\Delta}{g}}$ \\
\hline 0 & $\approx \approx$ & $\Xi \frac{\pi}{8}$ & & च & & 要 & & 도 & & $\stackrel{g}{g}$ & \\
\hline$\sigma$ & $\approx \approx$ & $\Xi \underset{\pi}{\pi}$ & & 푱 & & 要 & & 포 표 & & $\Xi \Xi$ & \\
\hline 0 & $\nsubseteq:=$ & $8 \frac{8}{1}$ & $\stackrel{2}{2}$ & $8 \frac{0}{8}$ & $\stackrel{\circ}{*}$ & 윰 & $\frac{8}{\pi}$ & $\circ \circ$ & 은 & ‡ & 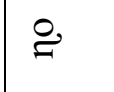 \\
\hline$\delta$ & & & & & & & & & & & \\
\hline 0 & $\cong$ & $\cong$ & & & & 氧 & & $\underline{0}$ & & $g:$ : & \\
\hline$=$ & & & & & & & 急 & & $\Xi \equiv$ & & \\
\hline 8 & 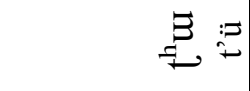 & & 䒠 & & $\frac{E}{6}: \frac{7}{8}$ & & 吾清 & & $\Xi \Xi$ & & 总青 \\
\hline$\lambda$ & & $3:$ & & $\vec{z}$ & & 疍: & & $\geq \equiv$ & & & \\
\hline- & & $=$ & & z & & & & & & छ & \\
\hline & $=$ & - & - & $\tau$ & $\sigma$ & $\ddot{g}$ & $\ddot{z}$ & - & - & $=$ & $\Rightarrow$ \\
\hline
\end{tabular}




\begin{tabular}{|c|c|c|c|c|c|c|c|c|}
\hline . & & & & & & & & \\
\hline$\stackrel{\Xi}{\sim}$ & & & & & & & & \\
\hline 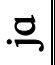 & & & & & & & & \\
\hline. & & & & & & & & \\
\hline 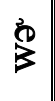 & & 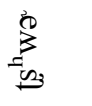 & & 总 & & & & 惫 \\
\hline 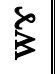 & & & & & & & & \\
\hline $\mathbb{3}$ & & & & & & & & \\
\hline$B$ & & 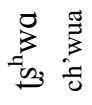 & & 总竞 & & & & 总 \\
\hline$>$. & & $z_{m}$ & & 至 & & $\vec{R}_{0}$ & & 胥 \\
\hline ¿6 & 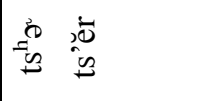 & 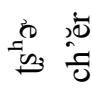 & $\stackrel{0}{0}$ & $\stackrel{s}{s}$ & & & 遏 & 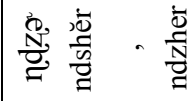 \\
\hline 0 & 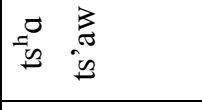 & & 总 & & & & 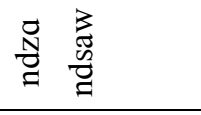 & \\
\hline$\sigma$ & $=0$ & & 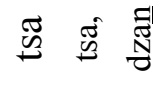 & & $\stackrel{\widetilde{y}}{\tilde{y}}$ & & 萠 & \\
\hline 0 & $\begin{array}{cc}0 & 0 \\
0 & 0\end{array}$ & 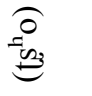 & 08 & & & & 焉 & \\
\hline$\delta$ & & 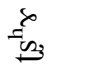 & & $\xi_{3}$ & & 稌 & & \\
\hline 0 & $=$ & & $\ddot{8}:$ : & & $\underset{y}{\mathscr{O}}$ & & & \\
\hline$=$ & & $=$ & $\underbrace{=}_{i=1}$ & 离吾 & & 胥 & & $\frac{\vec{z}}{\frac{7}{g}}$ \\
\hline$B$ & 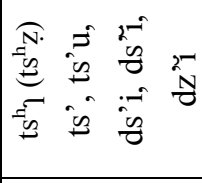 & 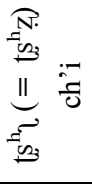 & 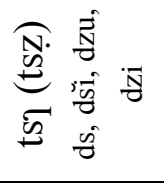 & 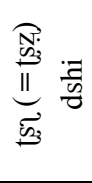 & 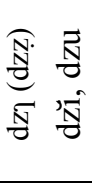 & 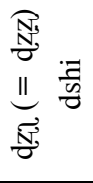 & 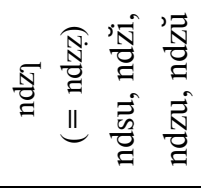 & 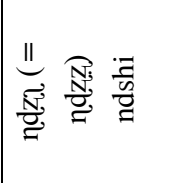 \\
\hline$\lambda$ & 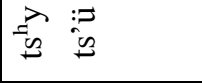 & & 梂 & & 정 & & 㫘 & \\
\hline$r$ & & & 氣 & & & & & \\
\hline & $=\infty$ & ${ }_{i 3}$ & $\approx$ & 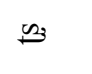 & $\stackrel{N}{0}$ & $\stackrel{N}{0}$ & $\stackrel{N}{=}$ & $\frac{N}{\breve{V}}$ \\
\hline
\end{tabular}




\begin{tabular}{|c|c|c|c|c|}
\hline . & & & & \\
\hline . & & & & \\
\hline 므 & & & & \\
\hline$\stackrel{\varrho}{\varrho}$ & $\frac{\widehat{E}}{\sqrt{n}}$ & & & \\
\hline 3 & & 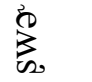 & & 莡 \\
\hline 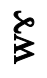 & & & & \\
\hline$\frac{\pi}{3}$ & & & & \\
\hline$B$ & & 离 & & 总竞 \\
\hline$>$. & & si & & $\vec{N}$ \\
\hline के & $\infty$ & $\stackrel{\infty}{\infty}$ & & $\mathbb{N}_{N}^{\infty}$ \\
\hline$\sigma$ & 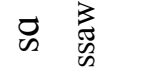 & & 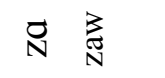 & \\
\hline$\pi$ & 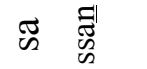 & $\mathscr{W}$ & $\mathbb{N} \underset{N}{\sim}$ & \\
\hline 0 & $\varnothing 8$ & \& & 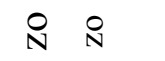 & \\
\hline 8 & & $\infty_{\infty} \frac{\overline{0}}{\infty}$ & & \\
\hline 0 & $\mathscr{m}$ & & 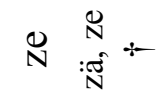 & \\
\hline$=$ & & $\vec{\infty}, \vec{z}$ & & $\vec{N} \frac{Z}{N}$ \\
\hline$B$ & 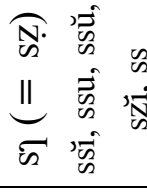 & $\begin{array}{l}\underset{\infty}{\mathbb{\infty}} \\
\underbrace{\|}_{\infty}\end{array}$ & 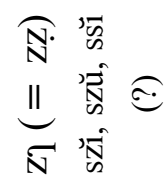 & $\begin{array}{l}\underbrace{\mathbb{N}_{3}}_{\vec{N}} \\
\text { II } \\
\text { ज }\end{array}$ \\
\hline$\lambda$ & 市: 融 & & 希: & \\
\hline$\rightarrow$ & $\vec{\omega}$ 它 & & $\vec{N}, \sqrt[S]{\infty}$ & \\
\hline & $\infty$ & $\infty$ & N & N \\
\hline
\end{tabular}




\begin{tabular}{|c|c|c|c|c|c|c|c|}
\hline . & $=$ & 悹 & & $\stackrel{0}{\stackrel{D}{S}}$ & & & \\
\hline. & 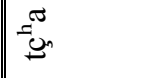 & 巴્త్ర & $\stackrel{\frac{\pi}{\pi}}{\pi}$ & 祃 & & & \\
\hline 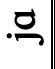 & & & & & & & \\
\hline$\stackrel{\wp}{\varrho}$ & & 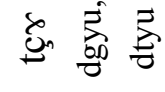 & $\stackrel{\overbrace{}}{\rightleftarrows}$ & 危 & $£$ & 吕 & \\
\hline 3 & & & & & & & \\
\hline 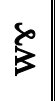 & & & & 高 & & & \\
\hline$\tilde{3}$ & & & & & & & \\
\hline 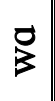 & $\frac{0}{3}$ & 店喜 & & & & $\sum_{x}^{0} \stackrel{0}{8}$ & \\
\hline$>$. & $\gtrsim \gtrsim$ & $\vec{z} \frac{\vec{y}}{b 0}$ & $b_{D} \vec{b}_{0}$ & 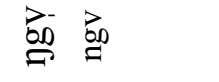 & 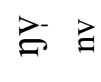 & ¿ 进 & \\
\hline co & & & & & & g] & \\
\hline 0 & 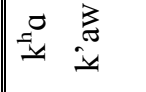 & $\stackrel{g}{\underline{y}}$ & & 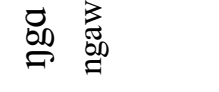 & $\stackrel{\circ}{\sigma}$ & $\vec{x} \underset{\Xi}{\stackrel{Z}{E}}$ & \\
\hline$\sigma$ & $\approx \ddot{\pi}$ & $\approx$ ت & & 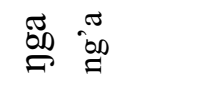 & & $\Xi \nsubseteq$ & \\
\hline 0 & 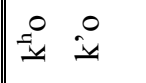 & $\stackrel{\circ}{\stackrel{9}{4}} \frac{8}{b 0}$ & & $\stackrel{\circ}{\stackrel{D}{g}}$ & & $\stackrel{9}{9}$ & \\
\hline 8 & $\cong$ & 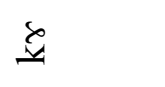 & 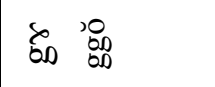 & 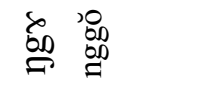 & $\left.\stackrel{8}{g}\right|_{\stackrel{0}{g}} ^{\circ}$ & $\check{x}$ & \\
\hline 0 & & & & & & $\mathscr{I}: \cong$ & \\
\hline$=$ & $=\vec{z}$ & $\underline{\vec{z}}$ 劵 & $\overrightarrow{E_{0}} \quad \overrightarrow{E_{0}}$ & 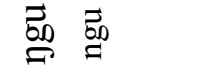 & & $\vec{x} \frac{\vec{z}}{\underline{\underline{x}}}$ & \\
\hline$B$ & $\begin{array}{lll}B & : 0 \\
\Perp & :\end{array}$ & $\underline{\underline{E}}$ & 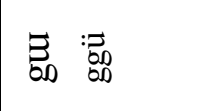 & 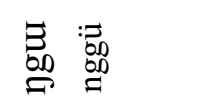 & & 灵 : & \\
\hline$\lambda$ & $\Rightarrow \frac{\lambda}{\underline{\underline{y}}}=$ & 강 $\frac{\vec{s}}{g}$ & 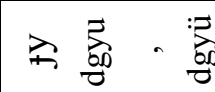 & 兊蛋 & & ટિ : & 心. \\
\hline \multirow[t]{2}{*}{-} & $\Rightarrow$ 菩 & $\overline{0}$ 窟 & $=\overrightarrow{6}$ & 胥愈 & 롤 & $\overline{o n}^{\prime} \bar{z}$ & \\
\hline & $=$ & 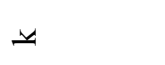 & on & $\stackrel{\circ D}{\Rightarrow}$ & $\Rightarrow$ & $=$ & un \\
\hline
\end{tabular}


Table 2 presents the inventory of initial consonants in the AS dialect - information which is already present in table 1, but can be visualised more conveniently in table 2. Semi-vowels are not included.

\begin{tabular}{|c|c|c|c|c|c|c|}
\hline & bilabials & dentals & retroflexes & palatals & velars & glottals \\
\hline stops & $p^{\mathrm{h}} \mathrm{p} \quad \mathrm{b} \quad \mathrm{mb}$ & $\mathrm{t}^{\mathrm{h}} \mathrm{t} d \mathrm{~d}$. & $\mathrm{t}^{\mathrm{h}} \mathrm{t} \mathrm{d}, \mathrm{nd}$ & & $\mathrm{k}^{\mathrm{h}} \mathrm{kg} \mathrm{jg}$ & \\
\hline affricates & & $\begin{array}{llll}\text { ts }^{\mathrm{h}} & \text { ts } & \mathrm{dz} & \mathrm{ndz}\end{array}$ & $\begin{array}{llll}\mathrm{ts}^{\mathrm{h}} & \text { ts } & \mathrm{dz} & \text { ndz }\end{array}$ & & & \\
\hline fricatives & & S z & S z & ç & & $\mathrm{h}$ \\
\hline nasals & $\mathrm{m}$ & $n$ & & & $y$ & \\
\hline $\begin{array}{l}\text { lateral } \\
\text { approximant } \\
\mathrm{s}\end{array}$ & & 1 & 1 & & & \\
\hline
\end{tabular}

Table 2. Initials in the AS dialect of Naxi (belonging to Western Naxi)

This inventory appears representative of Western Naxi dialects. It is somewhat larger than that of other dialects. The distinction between prenasalised stops and voiced stops is lost in many dialects, including Lijiang (Dayanzhen) and closely neighbouring dialects.

Figure 1 presents the rhymes of AS Naxi within the vocalic space. Rhymes with semi-vowels (/ja/, /jy/, / భe/, /wa/, /wa/, /wr/, and $/$ wrol) are placed next to their main vowel (e.g., for /wa/, vowel /a/). Allophones [ $\left.z_{2}\right]$ and $\left[z_{1}\right]$ of $/ \mathrm{w} /$ are not included. 


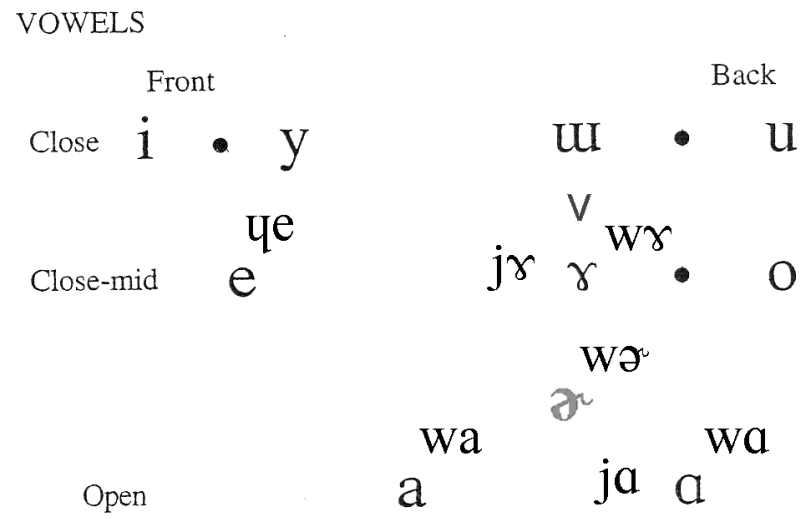

Figure 1. The rhymes of AS Naxi.

The notes below aim to clarify some of the data in table 1 .

\section{Palatalised velar consonants}

Several descriptions of Naxi (among which He Jiren and Jiang Zhuyi 1985, Fu Maoji 1981:297-316, Fang Guoyu and He Zhiwu 1995) write the phonetically palatalised velar consonants of Naxi as $/ \mathrm{t} c^{\mathrm{h}} /, / \mathrm{t} \mathrm{c} /, / \mathrm{d} \mathrm{z} /$ and $/ \mathrm{nd} z /$. This notation somewhat obscures the division of the syllable into initial and rhyme: 'to run', written as /dzỳ/, and 'eggplant', written as /gỳ/, are both considered to have an $/ \mathrm{s} /$ rhyme, whereas phonemic analysis reveals that these two words are /gjỳ/ and /gỳ/, respectively, the semi-vowel /j/ causing a palatalisation of the velar initial /g/. Once the opposition is rewritten as /gjỳ/ vs. /gỳ/, it turns out to be an opposition of rhymes, not of initials.

This reanalysis further offers a means of transcribing syllabic oppositions that could not be transcribed within the system used by these authors, for want of recognition of a /jy/ rhyme, e.g. they use /tcr/ for two combinations which are in fact distinct: /tjy/ and /kjr/. (To take an example, /kjý/ means 'to boil', /tjý/ means 'to fold up [clothes...]'.) 
The initial written as alveolo-palatal $/ \mathrm{z} /$ by these authors is $/ \mathrm{j} /$ in some cases (the word they write as $/ z \overline{\mathrm{a}} \mathrm{kò} /$, phonetically [jā kò], appears best analysed phonemically as /jā kò/); in other cases, it corresponds to the phonetic realisation of syllabic onset in the absence of an initial consonant: the syllable written /zi/, phonetically [ji], is simply an /i/ (see the first line in table 1).

Diachronically, it might be that two earlier forms, */njy/ and $* / \mathrm{njy} /$, merged to $[\mathrm{nr}]$; then again, there may not have been such a contrast in earlier states of the Naxi language. Synchronically, the contrast between $/ \mathrm{n} /$ and $/ \mathrm{y} /$ is neutralised in this position.

In table 1, we followed Martine Mazaudon's advice to transcribe the palatalised velars as palatals rather than alveolo-palatals (e.g. transcribing the phonetic realisation of $/ \mathrm{k}^{\mathrm{h}} \mathrm{i} /$ as [tç $\mathrm{h}$ ] rather than [t $\left.\mathrm{c}^{\mathrm{h}} \mathrm{i}\right]$ ), a notation which aims to bring out the fact that palatalisation is, on the whole, less advanced than in Mandarin Chinese (a language for which the notations $/ \mathrm{t} c^{\mathrm{h}} /, / \mathrm{t} c /, / \mathrm{c} /$ are standardly used).

\section{Trill allophone of $/ \mathrm{v} /$ after bilabial stops}

After a bilabial stop $/ \mathrm{p}^{\mathrm{h}} /, / \mathrm{p} /, / \mathrm{b} /$ or $/ \mathrm{mb} /$, the rhyme $/ \mathrm{v} /$ is realised as a voiced bilabial trill. (He Jiren and Jiang Zhuyi 1985:9 note this phonetic realisation by adding [ ${ }^{r}$ ], e.g. $\left[b^{r}{ }_{1}\right]$ for /bỵ/.) Phonetically, the syllable is realised as bilabial throughout; said differently, the rhyme adopts the place of articulation of the initial. This allophone of $/ \mathrm{v} /$ is written as a B in small capitals, [в], as proposed in the 1996 version of the International Phonetic Alphabet for a voiced bilabial trill (not to be confused with the bilabial fricative $[\beta]$ ).

In another dialect, that of $\mathrm{Feng}^{4} \mathrm{Ke}^{1}$ (for detailed coordinates see, in the present issue, "Three extreme cases of neutralisation: nasality, retroflexion and lip-rounding in Naxi"), / $\mathrm{p} /$ does not have a trilled allophone, e.g. /bṿ/ is realised [bṿ], not [B] as in AS. 


\section{Consonant /f/}

In 'native' Naxi vocabulary, [f] only appears in the syllable [fy], which can be analysed as /hṿ/: [f] is thus an allophone of $/ \mathrm{h} /$. (This is very similar to what is observed in Japanese, where [f] only appears as an allophone of $/ \mathrm{h} /$ before the vowel $/ \mathrm{u} /$.) Chinese borrowings have introduced the combinations $/ \mathrm{fe} /$, as in [fe '], 'tomb', from Chinese $\mathrm{fen}^{2} \mathrm{mu}^{4}$ 坟墓, and /fa/, e.g. as an equivalent of Chinese $\mathrm{fa}^{1}$ 发 and $\mathrm{fa}^{2}$ 罚, e.g. /tā fa”/ 'to get one's daughter married' ( $\mathrm{da}^{3} \mathrm{fa}^{1}$ 打发), /fa“ ${ }^{\prime} \mathrm{i} /$ 'to pronounce' (fa $\mathrm{yin}^{1}$ 发音). (The two tone diacritics on /fa”/ indicate a rising, Low-to-High lexical tone.)

Concluding note

The synchronic data provided here, and the tool for using Rock's transcription, hopefully contribute somewhat to clarifying the synchronic picture of Naxi phonemics. A task for the future will consist in engaging in comparative research on the basis of the increasing amount of synchronic data available.

\section{Acknowledgments}

Many thanks to Martine Mazaudon, Jacqueline Vaissière and the two reviewers of this paper for their useful comments and suggestions, and to the Naxi informants, colleagues and friends. Needless to say, the authors alone are responsible for remaining shortcomings.

\section{References}

BACOT Jacques (1913). Les Mosso, ethnographie des Mosso, leurs religions, leur langue et leur écriture, avec les documents historiques et géographiques relatifs à Li-kiang par Ed. Chavannes. Leiden: E.J. Brill. 
BENEDICT Paul K. (1972). Sino-Tibetan: A Conspectus. Cambridge: Cambridge University Press.

BØCKMAN Harald (1988). Naxi studies in China. A research report. Oslo, University of Oslo.

BRADLEY David (1975). Nahsi and Proto-Burmese-Lolo. Linguistics of the Tibeto-Burman Area, 2, no 1, pp. 93-150.

BU Jinrong 卜金荣 (1999). Naxi dongba wenhua yaoji ji chuancheng gailan 纳西东巴文化要籍及传承概览 $[A$ Survey of Naxi Dongba Culture Books and Inheritance], Kunming: Yunnan Minzu Chubanshe 云南民族出版社.

CAI Hua (1997). Une société sans père ni mari: les Na de Chine. Paris: Presses Universitaires de France.

FANG Guoyu 方国瑜 and HE Zhiwu 和志武 (1995). Naxi xiangxing wenzi pu 纳西象形文字谱 [A Dictionary of Naxi Pictographic Characters]. Kunming: Yunnan renmin chubanshe 云南人民出版社.

FU Maoji 傅檚勣 (vol. 1: 1981, vol. 2: 1984). Naxi-zu tuhua-wenzi “Bai bianfu qu jing ji” yanjiu 纳西语图画文字 《白蝙蝠取经记》研究 [A study of the Naxi pictographic manuscript "White Bat's Search for Sacred Books"], Computational Analyses of Asian and African Languages (Tokyo), Monograph Series 6.

GUO Dalie 郭大烈 and HE Zhiwu 和志武 (1999). Naxizu shi 纳西族史 [A History of the Naxi people]. Chongqing: Sichuan Minzu Chubanshe 四川民族出版社.

HE Jiren 和即仁 and JIANG Zhuyi 姜竹仪 (1985). Naxiyu jianzhi 纳西语简志 [A Brief Monography on the Naxi Language]. Beijing: Minzu Chubanshe 民族出版社 (Zhongguo shaoshu minzu yuyan jianzhi congshu 中国少数民族语言简志丛书). 
HE Zhiwu 和志武 (1987). Naxiyu Jichu Yufa 纳西语基础语法 [A Basic Grammar of Naxi]. Kunming: Yunnan Minzu Chubanshe 云南民族出版社.

JACKSON Anthony (1979). An analytical appraisal of the Na-khi ritual texts. The Hague: Mouton.

JACKSON Anthony (1989). Naxi studies: past, present and future. In: CHAO Chien and TAPP Nicholas (eds). Ethnicity and ethnic groups in China. Hong Kong: New Asia Academic Bulletin, vol. VIII.

LI Lincan 李霖灿, ZHANG Kun 张琨, HE Cai 和才 (1953). Moxie xiangxing wenzi zidian 麼些象形文字字典 [A dictionary of Moxie pictographs]. Hong Kong: Shuowenshe 说文社. Revised edition in 2001 by Yunnan Minzu Chubanshe 云南民族出版社, under the title Naxi xiangxing wenzi zidian 纳西象形文字字典 [A dictionary of Naxi pictographs], with some changes - and typos - in the phonetic transcriptions.

MATHIEU Christine (2003). A History and Anthropological Study of the Ancient Kingdoms of the Sino-Tibetan Borderland Naxi and Mosuo. Lewiston, NY: Edwin Mellen.

MATISOFF James A. (2003). Handbook of Proto-Tibeto-Burman: system and philosophy of Sino-Tibetan reconstruction. Berkeley \& Los Angeles: University of California Press.

MAZAUDON Martine and MICHAILOVSKY Boyd (1979). Naxi [Nahi]-English vocabulary. Unpublished manuscript.

McKHANN Charles F. (1995). The Naxi and the Nationalities Question. In: HARREL Steven (ed). Cultural Encounters on China's Ethnic Frontiers. Seattle: University of Washington Press. Pp. 39-62.

McKHANN Charles F. (1998). Naxi, Rerkua, Moso, Meng: Kinship, Politics and Ritual on the Yunnan-Sichuan Frontier. In: OPPITZ Michael and HSU Elisabeth (eds). Naxi and Moso Ethnography. Zürich: Völkerkundemuseum. Pp. 23-45. 
MUEGGLER Erik (2001). The Age of Wild Ghosts: Memory, Violence, and Place in Southwest China. Berkeley: University of California Press.

NISHIDA Tatsuo (1985). The Hsihsia, Lolo, and Moso languages. In: THURGOOD Graham, MATISOFF James A. and BRADLEY David (eds). Linguistics of the Sino-Tibetan Area: the state of the art. Papers presented to Paul K. Benedict for his 71 st birthday. Canberra, Australia: A.N.U.

OKRAND Marc (1974). Na-khi and Proto-Lolo-Burmese: A Preliminary Survey. Linguistics of the Tibeto-Burman Area, 1, no 1, pp. 55-97.

PINSON Thomas M. (1998). Naxi-Chinese-English Glossary, with English and Chinese Indexes. Dallas: Summer Institute of Linguistics.

ROCK Joseph (1963-1972). A Na-Khi -- English Encyclopedic Dictionary. Roma: Instituto Italiano per il Medio ed Estremo Oriente.

SUTTON Stephanne Barry (1974). In China's border provinces; the turbulent career of Joseph Rock, botanist-explorer. New York: Hastings House. 